\title{
Study on Entertainment Teaching Experiment for Track and Field in Physical Education Major
}

\author{
Wang Bin, \\ College of Physics Education \\ Neijiang Normal University \\ Neijiang, Sichuan, China
}

\author{
Li Xia \\ College of Physics Education \\ Neijiang Normal University \\ Neijiang, Sichuan, China
}

\begin{abstract}
By utilizing the method of documentation, experimental teaching in contrast, mathematical statistics to experimentally study on entertainment teaching experiment for track and field in physical education major, this paper puts forward that this teaching can not only creat the good teaching environment, effectively improve the teaching quality for track and field in P.E. major, but also effectively promote the process of popularity and socialization of track and field.
\end{abstract}

Keywords: teaching; physical education; Track and field; entertainment

\section{The proposition of the problem}

With the better understanding of sports, the function of traditional sports extend constantly under the newly historic condition. As the core of sports, track and field appear less in educational materials with less students who are fond of it. The survey shows that $70 \%$ of the students are not interesting in track and field with the main reason of lack of teaching interestedness and the factors and notion of entertainment. However, track and field is the key curriculum of P.E. major of which the aim is to cultivate the quality of teachers. How to strengthen the cognition of entertainment teaching of track and field based on the new characteristics of education development and the real need of the student with the carrier of track and field and measure of entertainment teaching not only is the inevitable subject of recent reform but also directly affects the development of track and field.

\section{Study objects and methods}

2.1. The study object consists of 50 P.E. majors in Grade 2009(each class with 25 students) of Department of P.E. of Neijiang Normal College.

2.2. Study methods

\subsubsection{Documentation method}

The related documents have been consulted to analyze the entertainment teaching and the experimental result of track and field.

\subsubsection{Method of xperimental teaching in contrast}

The control group adopted the regular teaching method while the experimental group adopted the method of entertainment teaching. The result of appraisal was contrasted and analyzed with the same method of appraisal after the experiment teaching.

\subsubsection{Mathemetical statistics method}

Statistics analysis software SPSS was applied to deal with the data from the survey to calculate the average value of related indicators and standard error criterion.

Methemetical statistics mehtod was applied to process the data gained from the experiment to decide if there were obvious differences of the results among the two groups and judge the effect of the experiment.

\section{The design and control of the experiment}

\subsection{The design of the experiment}

The 50 P.E. majors in Grade 2009 with similar situation of Department of P.E. of Neijiang Normal College randomly divided into two equal groups: experimental class and control class with the different teaching method and measure but similar basic factors.

The control class adopted the regular teaching method while 
the experimental class adopted the entertainment teaching method of track and field. Based on teaching task, aim, site, equipment and the actual conditions of the students, the latter teaching method fully have itself becom involved in the connotation and factors of entertainment and need much attention to funny and harmonious atmosphere, strengthen the interesteness of learning and have the subject position of the students been fully reflected.

\subsection{The control of the experiment}

To ensure the scientific, reasonable objects

of study, the 50 boys had been selected as study objects who pass the test of basic quality of track and field and tested by statistics with similar level of test indicators but no obvious differences and randomly divided into two classes(see Form 1). The form shows that the basic quality of the students in track and field of the two classes had no obvious differences which meeted the demand of the experiment via the test, $p>$ 0.05. During the experiment, the teaching content and arrangement of class time was same with the same teacher and teaching site. To ensure the scientific and specific test result, the students both in the two classes were mixed and then evaluated by the regular test standard with avoidance of the teacher.

Form 1 The test form of the basic quality of the students in track and field before the experimental teaching $\left( \pm_{\mathrm{S}}\right)$

\begin{tabular}{|c|c|c|c|c|c|c|}
\hline Group & $\mathrm{N}$ & $\begin{array}{l}\text { height } \\
\text { (metre) }\end{array}$ & $\begin{array}{l}30 \text { metres } \\
\text { ( second) }\end{array}$ & $\begin{array}{c}\text { stand long jump } \\
\text { (metre) }\end{array}$ & $\begin{array}{c}\text { shot } \\
\text { (metre) }\end{array}$ & $\begin{array}{r}800 \text { metres } \\
(\text { second })\end{array}$ \\
\hline \multicolumn{7}{|c|}{ Experimental } \\
\hline class & 25 & $1.73 \pm 0.46$ & $4.84 \pm 0.18$ & $2.39 \pm 0.11$ & $9.68 \pm 2.68$ & $126 \pm 5.62$ \\
\hline \multicolumn{7}{|c|}{ Control } \\
\hline class & 25 & $1.72 \pm 0.43$ & $4.77 \pm 0.19$ & $2.40 \pm 0.12$ & $9.70 \pm 2.63$ & $130 \pm 7.81$ \\
\hline $\mathrm{T}$ test & & $\mathrm{p}>0.05$ & $\mathrm{p}>0.05$ & $\mathrm{p}>0.05$ & $\mathrm{p}>0.05$ & $\mathrm{p}>0.05$ \\
\hline
\end{tabular}

$\mathrm{p}>0.05$ show that the basic quality of students in track and field is similar with no obvious differences

\section{The analysis of the result of the experiment}

\subsection{The entertainment teaching of the track and field creat the good teaching environment for the teachers and students}

\subsubsection{The entertainment teaching of track and field can effectively improve the initiative of learning}

Entertainment teaching of track and field means that the teachers and the students together take the activities with special pleasure sports methods, purpose, plan and organized understanding and practice to promote harmonious body and mental development ${ }^{[1]}$.

The essential characteristics is to refelect the interesting and humanity of the teaching with the element of entertainment. Teaching is a kind of talent-cultivation activity of mankind with both participation of the teachers and the students. What the teachers should do is to teach the students whilc what the students' task is to master knowledge and the way to gain knowledge in which process require mutually arduous efforts. Interesting is the inclination to strive for the understanding of something or for an activity. One would pay attention to or incline to one thing and then cause emotion when one is interested in this thing ${ }^{[2]}$. Anyone would be willing to pay for the his or her interests to gain twice the result with half the effort. Unbalanced cognition would usually result in the boredom of something and intensify the antagonistic sentiments. How to improve the level of cognition of track and field is based on changing the students' attitude and make them become interested in track and field to improve the initiative to study and transforom passivity accepting into initiative participating and then to 
achieve the aim to enhance the quality of teaching. The most urgent ability is the ability of gaining, applying and creating knowledge while the traditional teaching method and means with imparting knowledge as major just not attach enouth improtance to the other abilities ${ }^{[3]}$. Therefore, the innovation and transformation of the teaching method and means not only become the new choice but also would have improtant influence on the initiative of learning. First, the whold process from teaching design to experiment conbines the time needs, is premise with the improvement of the ability and quality of the students, pay much attention to creat funny and harmonious atmosphere, lay stress the respect to the subject position of the students, arouse the study motion and the ivitiative of participation to the class.

Second, the high sense of recognition of the students to entertainment teaching of track and field could offset the bodily discomfot caused by the direct experiences. The initiative and purpose have been strengthened and the students would gain knowledge and skills with initiative and funny.

At last, the teachers should strengthen the students' cognition level of track and field with creation of teaching notion, the renewal of knowledge connotation and breakthrough of the teaching method and means to fulfill the teaching aim by the high cognition of entertainment learning. Form 2 shows that above $85 \%$ of the students in experimental class were interested in track and field while only $24 \%$ of the students in control class were interested in it. The basic reason is the difference The basic reason is the disparity of the teaching means and method. The entertainment teaching could meet the needs of the students and pay attention to the mentality feeling and and interests to effectively improve the initiative of learing and strengthen the identity of track and field.

Form 2 The survey form of the cognition attitude to track and field both in experimental class and control class (\%)

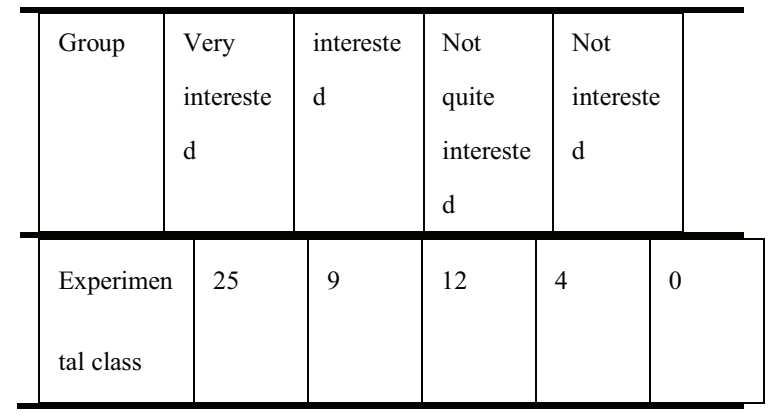

\begin{tabular}{|c|c|c|c|c|c|}
\hline $\begin{array}{l}\text { Percentage } \\
\%\end{array}$ & 36 & 48 & 16 & 0 & \\
\hline $\begin{array}{l}\text { Control } \\
\text { class }\end{array}$ & 25 & 2 & 4 & 12 & 7 \\
\hline $\begin{array}{l}\text { Percentage } \\
\%\end{array}$ & 8 & 16 & 48 & 28 & \\
\hline
\end{tabular}

4.1.2. The entertainment teaching of track and field could harmonize the relationship between the teachers and sudents

Harmonious relationship between the teachers and students means the mutual respect, equality and democracy, cooperation and exploration and mutual progress. The teachers could be the good teachers and helpful friends indeed. As a core relationship of school education, good relationship between the teachers and students is an essential way to improve the teaching quality ${ }^{[4]}$. During the class of track and field in P.E. major, the teaching method which teachers take a leading post has prevailed for a long time past. The class past not only repress the initiative and creativity of the students but also cause the conflict and contradiction in the class which could influence the quality of teaching. The entertainment teaching not only consists of learning of general knowledge but master the skill with a kind of dynamic, open, funny and repeatitive exercise. Therefore, the teaching should find out and extend the entertainment connotation of the project itself with new achievement of the sports, improve the interesting of learning, make the students become the leading role while the teachers as the guider and participant with the nature of advisers which do not make entertainment learning of track and field becomes a kind of burden or pressure ${ }^{[5]}$.However, "teachers-oriented"is the outstanding characteristics among all the ability teaching. Intimate the teachers and then believe their points. The students always be willing to learn for their favorite teachers $^{[[6]]}$. With perfect technique, thorough knowledge and affinity, the teachers should bring the students close and establish the harmonious relationship with the students to arouse the learning potentialities, self-esteem and confidence of the students. Entertainment teaching of track and field of P.E. major stresses on the new type of relationship with the equality, cooperation and mutual help of the teachers and the students and better reflect the teachers' respect, care to the 
students.

The check of track and field of P.E. majors not only demand the students to master the related theoretical knowledge but alos the stronger skill and the ability of teaching practice. Therefore, the content of the check should consist of theoretical knowledge, technical evaluatin and reaching the standard, teaching practice and the degree of participation of the students.

\subsection{Entertainment teaching of track and field}

As the first important matter, teaching quality is the eternal theme of the development of specialty construction of physical education which is also the essential guarantee to cultivate the students. Check is the method to evaluate the level of knowledge, the mirror of the teaching quality and the objective evaluation of the knowledge and skill via teaching activities after a period of time. The check of track and field of P.E. majors not only demand the students to master the related theoretical knowledge but alos the stronger skill and the ability of teaching practice. Therefore, the content of the check should consist of theoretical knowledge, technical evaluatin and reaching the standard, teaching practice and the degree of participation of the students.

Technical evaluation and the check to reach the standard are objectively reflected by mastering the knowledge and skill via teaching activities. There are differencts of the technical evaluation and the check between experimental class and control class which are showed in Form 3, Form 4 and Form 5. The forms show that the records of the technical evaluation, standard reaching, theory and teaching practice of experimental class are obvious higher than those of control class with great differences.

Form 3 The record table of technical evaluation of the students both in experimental class and control class

\begin{tabular}{lcccl}
\hline group & $\mathrm{N}$ & $\begin{array}{c}\text { Running } \\
\text { events }(-\mathrm{x})\end{array}$ & $\begin{array}{c}\text { Jumping } \\
\text { events }\end{array}$ & $\begin{array}{l}\text { Throwing } \\
\text { events }\end{array}$ \\
\hline experimental class & 25 & $93.3 \pm 3.6$ & $90.5 \pm 3.4$ & $91.5 \pm 3.7$ \\
control class & 25 & $78.3 \pm 4.3$ & $77.2 \pm 4.2$ & $82.1 \pm 3.2$ \\
$\mathrm{~T}$ & & 3.5 & 3.1 & 3.3 \\
$\mathrm{P}$ & $\mathrm{p}<0.05$ & $\mathrm{p}<0.05$ & $\mathrm{p}<0.05$ \\
\hline
\end{tabular}

Form 4 The record table of technical evaluation of the students both in experimental class and control class

\begin{tabular}{|c|c|c|c|c|}
\hline group & $\mathrm{N}$ & $\begin{array}{l}\text { Running } \\
\left.\text { events ( }{ }^{-} \mathrm{x}\right)\end{array}$ & $\begin{array}{c}\text { Jumping } \\
\text { events }\end{array}$ & $\begin{array}{l}\text { Throwing } \\
\text { events }\end{array}$ \\
\hline experimental class & 25 & $85.6 \pm 3.2$ & $87.3 \pm 4.1$ & $88.5 \pm 4.3$ \\
\hline control class & 25 & $78.3 \pm 5.2$ & $77.2 \pm 5.6$ & $80.1 \pm 6.1$ \\
\hline $\mathrm{T}$ & & 2.7 & 2.9 & 3.0 \\
\hline $\mathrm{P}$ & & 0.05 & $<0.05$ & $\mathrm{p}<0.05$ \\
\hline
\end{tabular}

Form 5 The record table of theory and teaching practice examination of the students both in experimental class and control class

\begin{tabular}{|c|c|c|c|c|}
\hline group & $\mathrm{N}$ & theory & $\begin{array}{l}\text { teaching } \\
\text { practice }\end{array}$ & Participation \\
\hline experimental class & 25 & $89.5 \pm 4.2$ & $92.3 \pm 3.7$ & $93.6 \pm 4.3$ \\
\hline control class & 25 & $81.3 \pm 4.1$ & $81.2 \pm 3.9$ & $76.1 \pm 4.6$ \\
\hline $\mathrm{T}$ & & 3.4 & 3.6 & 3.9 \\
\hline $\mathrm{P}$ & & $\mathrm{p}<0.05$ & $\mathrm{p}<0.05$ & $\mathrm{p}<0.05$ \\
\hline
\end{tabular}

4.3. The pioneering leading role of entertainment teaching of track and field

4.3.1. The entertainment teaching is benefical to the cultivation of the students' ability of innovation

Jiang Zeming once put forward thatinnovation sustains the progress of a nation, and an inexhaustible motive force for the prosperity of a country. The key of innovation is the talent whose growth depenging on education ${ }^{[7]}$. In addition, the work outling of the Ministry of Education in 2007 was to further deepen teaching reform, focus on the abilities of innovation and practice. The ability of innovation is the ability to apply knowldege and theory to put forward new thought, theory, method and creation with economic, social and ecological value in terms of the areas of science, art, technique and various practice activities. Innovation is the soul of the prograss of a nation and the core of economic competition. Current society competition is the competition of the ability of creation rather than the talents ${ }^{[8]}$. As the essential counterpart, the physical education has special effect on cultivating the ability of innovation ${ }^{[9]}$. The entertainment teaching of track and field, as one program of physical education, require to master the skills besides learning general knowledge which is a kind of teaching method to arouse the students' interests in track and field and bring the potential of sports ability and innovation.

4.3.2. The entertainment teaching of track and field is 
beneficial to cultivate the students' teaching skills

The students' teaching skills are usually gained by the experienced imparting of the teachers and education practice and the condition of the skills are influenced by various factors. At present, there are phenomenon of focusing on professional knowledge but overlooking the teaching. Many students were passive to accept due to the dull content which must influence the cultivation of teaching skills. The graduated students would not understand the teaching content enough with dull method after taking job. Entertainment teaching greatly improve the students' initiative of learning with various method and means and great interests. The abilities of teaching organization, language, action analysis and explanation have improved in the traditional program of track and field. The records of experimental class is obvious higher than those of control resulting from the students in experimental class applying the method of entertainment teaching.

4.3.3. Entertainment teaching is beneficial to the smooth implementation of the teaching task

Entertainment teaching creats a teaching environment with mutual respect, equality, education in amusement, active atmosphere, cooperation and mutual prograss which could decrease the gap between the students and teachers to further creat harmonious relationship which is the benificial factor to accomplish the teaching task smoothly. Entertainment teaching arouse the students' interests in track and field and enable them to seek, explore, practice and experience. This teaching animate the class with various method which enable the students to learn knowledge with the accomplishment of the teaching task.

\section{Conclusion}

5.1. Deal with the relationship between competitive teaching and entertainment teaching of track and field during the entertainment teaching, break the situation of the orientation towards competition, further strengthen the elements and notion of entertainment.

5.2. Strengthen the construction of the system of entertainment teaching, explore the teaching means and method which are operable, cultivate the certificated, type-compound P.E. talents who could meet the demands of social development as

5.3. Melt into element of entertainment based on the traditional teaching, strengthen the interests in study, improve the inner drive to learn track and field, promote the innovation and transfrom of the equipments to fit the teaching.

5.4. Establish the teaching system to fit entertainment teaching, strengthen the construction of educatinal materials, choose the teaching content painstakingly and effectively, innovate and transform the current project of track and field, strengthen the connotation of entertainment with partly competition and the construction of the team of the staff, improve the idea and level of entertainment teaching of track and field.

\section{REFERENCES}

[1] Zhou Hongping, The Contrast of the Effect Between Entertainment Teaching Method and Traditional Teaching method of Track and Field[J], Wuhan Physical Education College Journey, 2004,3:111

[2] Chu Yonghe, The Trouble of the Teaching of Track and Field in College and the Contermeasures[J], Liaoning Sports Science, 2002,2:32

[3] Zhong Binglin, The Promotion of the Reform of the Teaching Method and Teaching Means[J], Study on Teaching and Educational Materials, 2008,1:2

[4] Wangjing, The Exploration about the Theory of the Construction of Harmonious Relationship Between the Teachers and the Students Based on the Mordern Education[J], Education Space, 2011,9:158-159

[5] Wangbin, The Exploration of the Teaching Reform of Track and Field of Physical Education Major[J], Chengdu Physical Education College Journey, 2009,8:85

[6] Ma Jianhua, Creating Good Environment To Improve the Teaching Effect of Math Class[J], Jinan Education College Journey, 2001,1:43

[7] The Ministry of Education, Reference Material of Learning of Educational Action Plan Facing $21^{\text {st }}$ Century[M], Beijing, Beijing Normal University Press, 1999,4

[8] Creation[EB/OL],http://baike.baidu.com/view/301641.ht

[9] Bao Guangchang, Sports Teaching and the Cultivation of the Students' Ability of Creation 